\title{
Effects of drip irrigation on migration and distribution of heavy metals in soil profile
}

\author{
Binggan Wei ${ }^{1}$ - Jiangping Yu ${ }^{1}$ • Yunshe Dong ${ }^{1} \cdot$ Linsheng Yang $^{1} \cdot J^{1}$ g Wang ${ }^{1,2}$. \\ Yuan Xue ${ }^{1,2} \cdot$ Shufang Guo ${ }^{1,2}$
}

Received: 18 June 2015 / Accepted: 28 September 2015 / Published online: 22 October 2015

(C) Springer-Verlag Berlin Heidelberg 2015

\begin{abstract}
Drip irrigation systems have been widely applied in semiarid and arid regions of China. However, little is known about the migration of heavy metals in cultivated soil under drip irrigation. Therefore, the concentrations of $\mathrm{Cd}, \mathrm{Cr}, \mathrm{Cu}$, $\mathrm{Ni}, \mathrm{Pb}$, and $\mathrm{Zn}$ in soil were determined. The mean contents of $\mathrm{Cd}, \mathrm{Cr}, \mathrm{Cu}, \mathrm{Pb}, \mathrm{Zn}$, and $\mathrm{Ni}$ in surface soil subjected to irrigation with low and high amounts of water (W1 and W2) were $0.11,117.50,37.51,13.53,78.10$, and $38.41 \mathrm{mg} / \mathrm{kg}$ and 0.20 , $94.45,29.71,22.48,63.00$, and $36.62 \mathrm{mg} / \mathrm{kg}$, respectively. Metal concentrations in deep soil varied slightly between $\mathrm{W} 1$ and W2. Among different distances from the dropper, the metal levels in surface soil varied widely, while they varied slightly in deep soil. The $I_{\text {geo }}$ (geo-accumulation index) values indicated that the soil was usually contaminated by $\mathrm{Cr}, \mathrm{Cu}$, and $\mathrm{Cd}$. Under $\mathrm{W} 1, \mathrm{Cd}$ and $\mathrm{Cu}$ usually accumulated in surface soil near the dropper, while the other metals leached into subsurface soil. Moreover, the metals generally accumulated in soil away from the dropper. However, significant leaching of metals to the subsurface and deep soil was observed near the dropper under W2. Away from the dropper, $\mathrm{Cd}, \mathrm{Cr}, \mathrm{Cu}, \mathrm{Ni}$, and $\mathrm{Pb}$ usually accumulated in surface and deep soil. This
\end{abstract}

Responsible editor: Zhihong Xu

Binggan Wei

weibg@igsnrr.ac.cn

$\triangle$ Linsheng Yang

yangls@igsnrr.ac.cn

1 Key Laboratory of Land Surface Pattern and Simulation, Institute of Geographical Sciences and Natural Resources Research, Chinese Academy of Sciences, Beijing, China

2 University of Chinese Academy of Sciences, Beijing, China suggested that heavy metals generally migrated to the soil away from the dropper when subjected to lower amounts of irrigation, while metals usually moved to surface soil and deep soil under high irrigation amounts. These findings indicate that drip irrigation greatly affected the distribution and migration of heavy metals in soil, with irrigation with lower amounts of irrigation water significantly affecting the horizontal migration of heavy metals and higher amounts influencing the vertical movement of heavy metals.

Keywords Heavy metals $\cdot$ Drip irrigation $\cdot$ Soil $\cdot$ Migration

\section{Introduction}

Drip irrigation systems have increasingly been used to supply irrigation water, fertilizers, and pesticides to a wide range of vegetables, field crops, and fruit trees due to their ability to enable highly localized application of water and nutrients to crops (Kandelous et al. 2011; Selim et al. 2013). Many investigations have been conducted to investigate the migration characteristics of water and salt in soil under drip irrigation. Variations of water content in surface soil were found to be larger under drip irrigation than under flood and furrow irrigation. For example, a half-conical humid area around the periphery was formed under drip irrigation, while a Ushaped humid area around the periphery was formed under furrow irrigation (Zheng et al. 2011). Drip irrigation significantly impacted the distribution of salt in soil; however, salt content in the deep soil layer was only slightly influenced $\mathrm{Hu}$ et al. 2011). Spatially, the accumulation of salt in the vertical direction gradually increased at $0-80 \mathrm{~cm}$ and then slightly increased at $80-120 \mathrm{~cm}$ under drip irrigation (Hu et al. 2011). The accumulation of salt in the horizontal direction 
was greater at the center of open ground than in the other position. Salt rarely accumulated under the drop tap (Maimaitiniyazi et al. 2011). Liu et al. (2013) reported that drip irrigation strongly affected the distributions and changes of water and salts in soil. Salts obviously accumulated in the 0 to $60-\mathrm{cm}$ soil layer, particularly in the 20 - to $60-\mathrm{cm}$ soil layer, while salt content in the 60 - to 100 -cm soil layer varied slightly. Moreover, salts accumulated in the 0 - to $60-\mathrm{cm}$ soil layer were usually leached into deeper soil layers after the $150-\mathrm{mm}$ winter irrigation and thawing during the following next spring. The distributions of water and salts in soil under drip irrigation were usually affected by irrigation amount. A greater amount of irrigation water induced a significantly lower accumulation of soil salts (Guan et al. 2013). Distribution of water in the soil profile under drip irrigation was affected by the distance from the drippers (Badr and Abuarab 2013). The distribution and transportation of water and salt in the soil profile were also significantly influenced by drip tape arrangement (Liu et al. 2012). Furthermore, the distribution of salt in soil varied widely with different reclaimed years under drip irrigation (Tan et al. 2009).

In recent years, increasing attention has been focused on heavy metal contamination in the environment because of their toxicity (Koedrith et al. 2013; Soodan et al. 2014; Soltani et al. 2015; Wei et al. 2010). Metals are particularly hazardous because of their ubiquity, toxicity, and persistence (Burges et al. 2015; Luo et al. 2015). Heavy metals in agricultural soil enter the human body via the food chain, after which they induce a series of health effects (Al-Hwaiti and AlKhashman 2015; Cheraghi et al. 2012; Rai et al. 2015; Savic et al. 2015). For instance, intake of $\mathrm{Pb}$ was found to damage the nervous, skeletal, circulatory, enzyme, endocrine, and immune systems of humans (Zhang et al. 2012). Additionally, chronic exposure to $\mathrm{Cd}$ and As induced malignancy, benign prostatic hyperplasia, hypertension, skin lesions, skin cancer, vascular diseases, and nervous system diseases (Yang et al. 2002; Żukowska and Biziuk 2008). Moreover, many investigations have reported that irrigation and fertilizer caused heavy metal contamination in soil (Baldantoni et al. 2010; Negreanu et al. 2012; Surdyk et al. 2010; Wei and Yang 2010; Zhou et al. 2014). Cheraghi et al. (2012) suggested that long-term application of phosphatic fertilizer induced cadmium contamination in soil. Irrigation usually changes the physical and chemical properties of soil (Fonseca et al. 2005), as well as the migration, species, bioavailability, and leaching of heavy metals in soil (Qiao et al. 2011). These results imply that drip irrigation may induce a unique distribution of heavy metals in soil, as well as their migration patterns, which may affect food security.

However, most investigations conducted to date have focused on migration and distribution of water and salts in cultivated soil under drip irrigation, while few have evaluated the migration of heavy metals. Moreover, little is known about the migration and distribution of heavy metals in soils impacted by drip irrigation. Therefore, the present study was conducted to (1) determine the concentrations of $\mathrm{Cd}, \mathrm{Cu}, \mathrm{Cr}, \mathrm{Ni}, \mathrm{Pb}$, and $\mathrm{Zn}$ in soil under drip irrigation, (2) evaluate contamination levels of heavy metals, and (3) investigate the distributions of heavy metals in soil profiles.

\section{Materials and methods}

\section{Study area}

Pingluo County located in the arid region of Ningxia, China, was selected for the study area (Fig. 1). Pingluo is characterized by a temperate continental and arid climate with an average annual precipitation of $184 \mathrm{~mm}$. At present, approximately $900 \mathrm{~km}^{2}$ of cultivated land in the region is irrigated by drip irrigation.

\section{Sampling}

In the study area, different irrigation water amounts were used to irrigate the cultivated land planting with maize. The migration patterns of heavy metals in soil may vary widely under different irrigation amounts. Therefore, the distributions of heavy metals in soils that received low water amounts (W1; irrigation water amount $=115 \mathrm{~mm}$ ) and high irrigation water amounts (W2; irrigation water amount $=230 \mathrm{~mm}$ ) were investigated in the present study. Soil samples were collected from soil profiles of areas irrigated with two adjacent droppers under W1 and W2 in September 2013 (Fig. 1). Each soil sample consisted of a mixture of three subsamples in three soil profiles subjected to each irrigation water amount. About $500 \mathrm{~g}$ of soil was collected and gathered into a self-sealing polyethylene bag for each soil sample, after which the samples were transferred to the laboratory for further analysis.

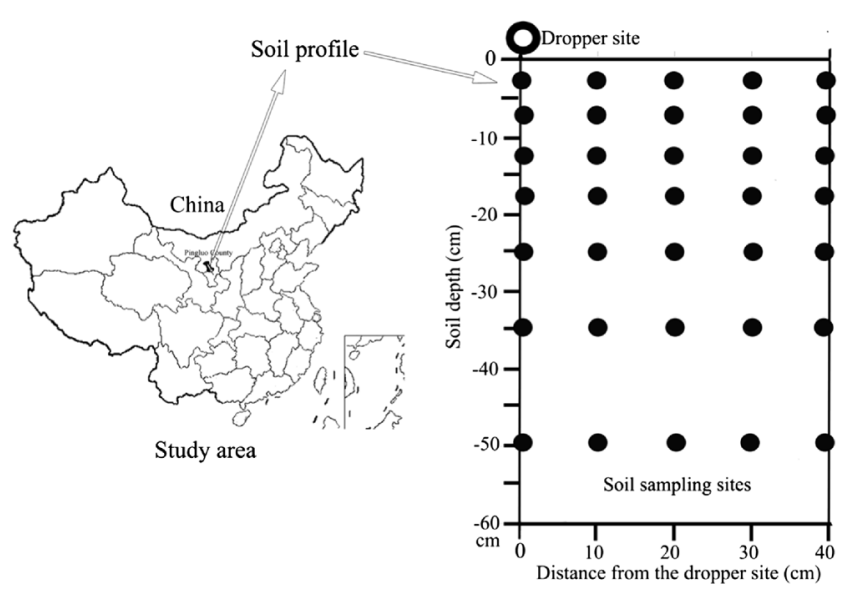

Fig. 1 Sketch map of study area and soil sampling points in the soil profile 


\section{Sample processing}

All soil samples were air-dried to constant weight, after which they were pulverized and passed through a nylon sieve with a diameter of $\leq 0.149 \mathrm{~mm}$. About $0.1 \mathrm{~g}$ of the sieved soil samples were then digested with a 5:2:1 mixture of $\mathrm{HNO}_{3}: \mathrm{H}_{2} \mathrm{SO}_{4}: \mathrm{HF}$ and allowed to stand overnight. The solution was then heated at $120^{\circ} \mathrm{C}$ for $30 \mathrm{~min}$, followed by $150{ }^{\circ} \mathrm{C}$ for $30 \mathrm{~min}, 200^{\circ} \mathrm{C}$ for $30 \mathrm{~min}$, and then $260-270{ }^{\circ} \mathrm{C}$ for $1 \mathrm{~h}$ each. Finally, the digested solution was diluted to $50 \mathrm{ml}$ with deionized water. The samples were then analyzed for $\mathrm{Cd}, \mathrm{Cr}$, $\mathrm{Cu}, \mathrm{Ni}, \mathrm{Pb}$, and $\mathrm{Zn}$ by inductively coupled plasma-mass spectrometry (ICP-MS). Quality controls consisted of (1) analysis of 12 random samples and four national standard samples and (2) random selection of samples to ensure that the mean deviation was less than $3 \%$.

\section{Data analysis}

All statistical analyses were performed using Microsoft Excel 2007 and SPSS V18.0 for Windows. Moreover, spatial distribution maps of heavy metal concentrations in the soil profile were generated by Kriging interpolating data using Surfer 10.0 .

\section{Methods of heavy metal pollution assessment}

The geo-accumulation index $\left(I_{\text {geo }}\right)$ introduced by Muller has been used since the late 1960s and has been widely employed in heavy metal studies (Muller 1969; Rajmohan et al. 2014). The $I_{\text {geo }}$ was used to assess heavy metal contamination in soils by comparing current and pre-industrial concentrations, although it was not always easy to reach pre-industrial sediment layers. It was also used to assess heavy metal pollution in agricultural soil. The geo-accumulation index was expressed as follows (Muller 1969):

$I_{\text {geo }}=\log _{2}\left(C_{n} / 1.5 B_{n}\right) I_{\text {geo }}$

where $C_{n}$ is the concentration of the element in soil and $B_{n}$ is the background value. In this study, the background values of the metals in Ningxia (CNEMC 1990) were selected to calculate the $I_{\text {geo }}$ values. The constant 1.5 allows analysis of natural fluctuations in the content of a given substance in the environment and detection of very small anthropogenic influences (Ji et al. 2008). The geo-accumulation index consisted of seven classes. The following terminologies were used to describe the contamination level of heavy metal: $I_{\text {geo }} \leq 0$, practically uncontaminated; $0<I_{\text {geo }} \leq 1$, uncontaminated to moderately contaminated; $1<I_{\text {geo }} \leq 2$, moderately contaminated; $2<I_{\text {geo }} \leq 3$, moderately to heavily contaminated; $3<I_{\text {geo }} \leq 4$, heavily contaminated; $4<I_{\text {geo }} \leq 5$, heavily to extremely contaminated; and $I_{\text {geo }}>5$, extremely contaminated.

\section{Results}

\section{Heavy metal in soil}

Table 1 shows the concentrations of the metals in surface soil $(0-20 \mathrm{~cm})$ and deep soil $(20-60 \mathrm{~cm})$ under W1. The mean contents of $\mathrm{Cd}, \mathrm{Cr}, \mathrm{Cu}, \mathrm{Pb}, \mathrm{Zn}$, and Ni were $0.11,117.50$, $37.51,13.53,78.10$, and $38.41 \mathrm{mg} / \mathrm{kg}$ in the surface soil, respectively, while they were $0.13,116.82,37.10,16.28,55.54$, and $32.38 \mathrm{mg} / \mathrm{kg}$ in deep soil. These findings indicated that the mean concentration of $\mathrm{Zn}$ was much higher in the surface soil than in the deep soil, while the mean contents of the other metals varied slightly between surface soil and in deep soil. When compared with their background values, the concentrations of $\mathrm{Cr}$ and $\mathrm{Cu}$ were usually higher in surface and deep soils, while $\mathrm{Zn}$ levels were higher in surface soil.

The heavy metal concentrations in soil under $\mathrm{W} 2$ are listed in Table 2. The mean contents of $\mathrm{Cd}, \mathrm{Cr}, \mathrm{Cu}, \mathrm{Pb}, \mathrm{Zn}$, and $\mathrm{Ni}$ were $0.20,94.45,29.71,22.48,63 ., 00$ and $36.62 \mathrm{mg} / \mathrm{kg}$ in the surface soil, respectively, while they were $0.17,94.71,29.91$, $22.45,70.46$, and $33.24 \mathrm{mg} / \mathrm{kg}$ in deep soil. Among surface soil and deep soil, the mean concentrations of the determined metals varied slightly. With the exception of $\mathrm{Pb}$ and $\mathrm{Ni}$, the concentrations of the other metals were higher than their background values.

The mean concentrations of $\mathrm{Cr}$ and $\mathrm{Cu}$ in both surface soil and deep soil were usually higher under W1 than W2, while the values of the other metals varied slightly. Additionally, the concentrations of $\mathrm{Cr}, \mathrm{Cu}, \mathrm{Ni}, \mathrm{Pb}$, and $\mathrm{Zn}$ in surface soils under both $\mathrm{W} 1$ and $\mathrm{W} 2$ varied widely among different distances away from the dropper site. The Cd contents in both surface and deep soil varied obviously among distances away from dropper site under both W1 and W2. However, the concentrations of $\mathrm{Cr}, \mathrm{Cu}, \mathrm{Ni}, \mathrm{Pb}$, and $\mathrm{Zn}$ in deep soils varied slightly among distances from the dropper site.

\section{$I_{\text {geo }}$ for heavy metal in soil}

The $I_{\text {geo }}$ values for the metals in surface soil under $\mathrm{W} 1$ and $\mathrm{W} 2$ are shown in Tables 3 and 4 . The $I_{\text {geo }}$ values for $\mathrm{Pb}, \mathrm{Zn}$, and $\mathrm{Ni}$ in surface soil under both W1 and W2 were generally lower than 0 . The $I_{\text {geo }}$ values for $\mathrm{Cr}$ and $\mathrm{Cu}$ under $\mathrm{W} 1$ and $\mathrm{Cd}$ and $\mathrm{Cr}$ under W2 were usually higher than 0 . Moreover, the $I_{\text {geo }}$ value for $\mathrm{Cd}$ was lower than 0 under $\mathrm{W} 1$, while the value was higher than 0 under W2.

\section{Distributions of heavy metals in soil}

The distance between adjacent droppers in the study area was $80 \mathrm{~cm}$. Heavy metal concentrations in soil samples from the soil profile (depth, 0-60 cm; distance from dropper, $0-40 \mathrm{~cm}$ ) were analyzed. The distributions of metal 
Table 1 Heavy metal concentrations in soil under W1 (mg/kg)

\begin{tabular}{|c|c|c|c|c|c|c|}
\hline Distance from the dropper & $\mathrm{Cd}$ & $\mathrm{Cr}$ & $\mathrm{Cu}$ & $\mathrm{Pb}$ & $\mathrm{Zn}$ & $\mathrm{Ni}$ \\
\hline \multicolumn{7}{|l|}{ Surface soil $(0-20 \mathrm{~cm})$} \\
\hline $0 \mathrm{~cm}$ & $0.19 \pm 0.20$ & $92.68 \pm 26.77$ & $38.01 \pm 14.96$ & $10.74 \pm 6.39$ & $40.42 \pm 33.15$ & $24.85 \pm 9.12$ \\
\hline $10 \mathrm{~cm}$ & $0.12 \pm 0.15$ & $111.84 \pm 15.06$ & $35.57 \pm 6.13$ & $13.18 \pm 7.49$ & $55.02 \pm 11.85$ & $31.17 \pm 6.95$ \\
\hline $20 \mathrm{~cm}$ & $0.04 \pm 0.05$ & $102.77 \pm 38.76$ & $26.96 \pm 7.58$ & $12.68 \pm 5.05$ & $38.79 \pm 20.85$ & $27.41 \pm 25.95$ \\
\hline $30 \mathrm{~cm}$ & $0.06 \pm 0.05$ & $119.20 \pm 31.69$ & $36.66 \pm 3.78$ & $13.97 \pm 4.97$ & $161.56 \pm 68.58$ & $44.97 \pm 22.77$ \\
\hline $40 \mathrm{~cm}$ & $0.12 \pm 0.09$ & $161.02 \pm 43.55$ & $50.34 \pm 9.89$ & $17.06 \pm 9.27$ & $94.72 \pm 17.72$ & $63.65 \pm 12.94$ \\
\hline Mean & $0.11 \pm 0.12$ & $117.50 \pm 37.76$ & $37.51 \pm 11.28$ & $13.53 \pm 6.87$ & $78.10 \pm 27.39$ & $38.41 \pm 20.56$ \\
\hline \multicolumn{7}{|l|}{ Deep soil $(20-60 \mathrm{~cm})$} \\
\hline $0 \mathrm{~cm}$ & $0.30 \pm 0.27$ & $111.65 \pm 13.98$ & $41.64 \pm 9.23$ & $22.59 \pm 13.04$ & $78.39 \pm 42.86$ & $23.94 \pm 9.25$ \\
\hline $10 \mathrm{~cm}$ & $0.13 \pm 0.10$ & $95.90 \pm 24.85$ & $30.04 \pm 7.46$ & $8.57 \pm 4.98$ & $40.90 \pm 17.59$ & $45.58 \pm 19.27$ \\
\hline $20 \mathrm{~cm}$ & $0.15 \pm 0.17$ & $108.81 \pm 41.51$ & $31.41 \pm 5.20$ & $13.75 \pm 9.07$ & $40.60 \pm 8.52$ & $26.64 \pm 8.24$ \\
\hline $30 \mathrm{~cm}$ & $0.03 \pm 0.02$ & $127.19 \pm 19.32$ & $36.45 \pm 1.74$ & $18.88 \pm 2.48$ & $61.82 \pm 6.43$ & $32.17 \pm 7.96$ \\
\hline $40 \mathrm{~cm}$ & $0.05 \pm 0.02$ & $140.57 \pm 22.07$ & $45.95 \pm 10.82$ & $17.60 \pm 5.29$ & $55.99 \pm 9.68$ & $33.59 \pm 14.03$ \\
\hline Mean & $0.13 \pm 0.16$ & $116.82 \pm 27.25$ & $37.10 \pm 8.94$ & $16.28 \pm 8.70$ & $55.54 \pm 23.46$ & $32.38 \pm 13.14$ \\
\hline Background value & 0.10 & 59.70 & 20.90 & 20.10 & 56.40 & 36.10 \\
\hline
\end{tabular}

contents in the whole soil profile between the two droppers are presented in the figures.

Figure 2 shows the distributions of metals in soil under W1. Higher levels of $\mathrm{Cd}, \mathrm{Cu}$, and $\mathrm{Zn}$ were observed in surface soil under the dropper area, while the levels of $\mathrm{Cr}, \mathrm{Ni}$, and $\mathrm{Pb}$ were lower. The concentrations of $\mathrm{Cr}, \mathrm{Cu}, \mathrm{Ni}, \mathrm{Pb}$, and $\mathrm{Zn}$ in both surface soil and deep soil were significantly higher in the middle part between adjacent droppers. The highest $\mathrm{Cd}$ concentration was found in surface soil and deep soil under the dropper area. In the subsurface soil $(10-30 \mathrm{~cm})$ away from the dropper $(20-40 \mathrm{~cm})$, the $\mathrm{Cd}$ concentration was higher, while it was very low in the other areas. The Cr levels in surface soil and deep soil were generally high in the area away from the dropper and low in other areas, with the lowest values observed in the surface soil. $\mathrm{Cu}$ values in surface soil and deep soils near the dropper and in soil away from the dropper were usually higher than in other areas. The highest Ni content was observed in surface soil away from the dropper, while the lowest values were found in subsurface soil near the dropper. The $\mathrm{Pb}$ levels in the subsurface soil in the vicinity of the dropper as well as in the surface soil and deep soil away from the dropper were higher than in the other areas. The highest

Table 2 Heavy metal concentrations in soil under W2 $(\mathrm{mg} / \mathrm{kg})$

\begin{tabular}{|c|c|c|c|c|c|c|}
\hline Distance from the dropper & $\mathrm{Cd}$ & $\mathrm{Cr}$ & $\mathrm{Cu}$ & $\mathrm{Pb}$ & $\mathrm{Zn}$ & $\mathrm{Ni}$ \\
\hline \multicolumn{7}{|l|}{ Surface soil $(0-20 \mathrm{~cm})$} \\
\hline $0 \mathrm{~cm}$ & $0.19 \pm 0.05$ & $86.98 \pm 22.72$ & $26.47 \pm 4.52$ & $22.98 \pm 5.87$ & $49.85 \pm 16.24$ & $36.65 \pm 11.67$ \\
\hline $10 \mathrm{~cm}$ & $0.16 \pm 0.01$ & $98.01 \pm 17.27$ & $31.19 \pm 2.22$ & $22.58 \pm 6.11$ & $71.99 \pm 11.03$ & $32.41 \pm 3.55$ \\
\hline $20 \mathrm{~cm}$ & $0.21 \pm 0.08$ & $98.71 \pm 21.11$ & $30.23 \pm 4.54$ & $22.27 \pm 7.45$ & $68.52 \pm 11.43$ & $40.45 \pm 29.76$ \\
\hline $30 \mathrm{~cm}$ & $0.26 \pm 0.11$ & $101.02 \pm 12.65$ & $30.83 \pm 2.99$ & $24.77 \pm 3.61$ & $58.93 \pm 19.84$ & $35.77 \pm 5.03$ \\
\hline $40 \mathrm{~cm}$ & $0.19 \pm 0.03$ & $87.56 \pm 15.82$ & $29.81 \pm 3.59$ & $19.78 \pm 4.42$ & $65.70 \pm 6.49$ & $37.81 \pm 8.30$ \\
\hline Mean & $0.20 \pm 0.07$ & $94.45 \pm 17.35$ & $29.71 \pm 3.70$ & $22.48 \pm 5.29$ & $63.00 \pm 14.67$ & $36.62 \pm 13.62$ \\
\hline \multicolumn{7}{|l|}{ Deep soil $(20-60 \mathrm{~cm})$} \\
\hline $0 \mathrm{~cm}$ & $0.18 \pm 0.03$ & $99.85 \pm 12.17$ & $32.27 \pm 3.15$ & $24.00 \pm 2.21$ & $76.92 \pm 19.93$ & $35.64 \pm 5.66$ \\
\hline $10 \mathrm{~cm}$ & $0.15 \pm 0.02$ & $97.35 \pm 26.02$ & $28.36 \pm 3.84$ & $21.91 \pm 9.36$ & $85.46 \pm 6.11$ & $26.94 \pm 5.49$ \\
\hline $20 \mathrm{~cm}$ & $0.15 \pm 0.03$ & $95.96 \pm 15.42$ & $30.9 \pm 1.79$ & $19.52 \pm 2.64$ & $62.13 \pm 9.73$ & $29.80 \pm 8.54$ \\
\hline $30 \mathrm{~cm}$ & $0.19 \pm 0.11$ & $76.98 \pm 15.41$ & $26.06 \pm 4.69$ & $22.04 \pm 7.16$ & $56.10 \pm 7.76$ & $36.61 \pm 24.10$ \\
\hline $40 \mathrm{~cm}$ & $0.19 \pm 0.03$ & $103.43 \pm 12.47$ & $31.98 \pm 2.67$ & $24.80 \pm 1.88$ & $71.69 \pm 6.12$ & $37.20 \pm 6.89$ \\
\hline Mean & $0.17 \pm 0.05$ & $94.71 \pm 17.30$ & $29.91 \pm 3.76$ & $22.45 \pm 5.07$ & $70.46 \pm 14.36$ & $33.24 \pm 11.28$ \\
\hline Background value & 0.10 & 59.70 & 20.90 & 20.10 & 56.40 & 36.10 \\
\hline
\end{tabular}


Table 3 The $I_{\text {geo }}$ values for the determined metals in surface soil under W1

\begin{tabular}{lllllll}
\hline Distance from the dropper & $\mathrm{Cd}$ & $\mathrm{Cr}$ & $\mathrm{Cu}$ & $\mathrm{Pb}$ & $\mathrm{Zn}$ & $\mathrm{Ni}$ \\
\hline Surface soil (0-20 cm) & & & & & & \\
$0 \mathrm{~cm}$ & 0.32 & 0.05 & 0.28 & -1.49 & -1.07 & -1.12 \\
$10 \mathrm{~cm}$ & -0.36 & 0.32 & 0.18 & -1.19 & -0.62 & -0.8 \\
$20 \mathrm{~cm}$ & -1.99 & 0.2 & -0.22 & -1.25 & -1.12 & -0.98 \\
$30 \mathrm{~cm}$ & -1.32 & 0.41 & 0.23 & -1.11 & 0.93 & -0.27 \\
$40 \mathrm{~cm}$ & -0.4 & 0.85 & 0.68 & -0.82 & 0.16 & 0.23 \\
Mean & -0.54 & 0.39 & 0.26 & -1.16 & -0.12 & -0.50 \\
Deep soil (20-60 cm) & & & & & & \\
$0 \mathrm{~cm}$ & 1.00 & 0.32 & 0.41 & -0.42 & -0.11 & -1.18 \\
$10 \mathrm{~cm}$ & -0.21 & 0.10 & -0.06 & -1.81 & -1.05 & -0.25 \\
$20 \mathrm{~cm}$ & 0.00 & 0.28 & 0.00 & -1.13 & -1.06 & -1.02 \\
$30 \mathrm{~cm}$ & -2.32 & 0.51 & 0.22 & -0.68 & -0.45 & -0.75 \\
$40 \mathrm{~cm}$ & -1.58 & 0.65 & 0.55 & -0.78 & -0.60 & -0.69 \\
Mean & -0.21 & 0.38 & 0.24 & -0.89 & -0.61 & -0.74 \\
\hline
\end{tabular}

levels of $Z n$ were found in surface soil away from the dropper. $\mathrm{Zn}$ contents in surface soil near the dropper were usually higher.

As shown in Fig. 3, the Cd concentrations in surface soil and deep soil away from the dropper were generally higher than the other parts under W2. The Cr values under the dropper area were obviously lower, while $\mathrm{Cr}$ levels in subsurface soil were generally lower than in the other areas. Similarly, lower $\mathrm{Cu}$ levels were found in a small area near the dropper. In subsurface soil, the highest Ni concentrations were usually observed. The values in deep soil away from the dropper were higher. In subsurface soil and deep soil, $\mathrm{Pb}$ contents were much higher than in other areas. The highest $\mathrm{Zn}$ levels were

Table 4 The $I_{\text {geo }}$ of the determined metals in surface soil under W2

\begin{tabular}{lllllll}
\hline Distance from the dropper & $\mathrm{Cd}$ & $\mathrm{Cr}$ & $\mathrm{Cu}$ & $\mathrm{Pb}$ & $\mathrm{Zn}$ & $\mathrm{Ni}$ \\
\hline Surface soil (0-20 cm) & & & & & & \\
$0 \mathrm{~cm}$ & 0.28 & -0.04 & -0.24 & -0.39 & -0.76 & -0.56 \\
$10 \mathrm{~cm}$ & 0.07 & 0.13 & -0.01 & -0.42 & -0.23 & -0.74 \\
$20 \mathrm{~cm}$ & 0.48 & 0.14 & -0.05 & -0.48 & -0.3 & -0.42 \\
$30 \mathrm{~cm}$ & 0.76 & 0.17 & -0.02 & -0.28 & -0.52 & -0.6 \\
$40 \mathrm{~cm}$ & 0.31 & -0.03 & -0.07 & -0.61 & -0.36 & -0.52 \\
Mean & 0.42 & 0.08 & -0.08 & -0.42 & -0.43 & -0.56 \\
Deep soil (20-60 cm) & & & & & & \\
$0 \mathrm{~cm}$ & 0.26 & 0.16 & 0.04 & -0.33 & -0.14 & -0.60 \\
$10 \mathrm{~cm}$ & 0.00 & 0.12 & -0.14 & -0.46 & 0.01 & -1.01 \\
$20 \mathrm{~cm}$ & 0.00 & 0.10 & -0.02 & -0.63 & -0.45 & -0.86 \\
$30 \mathrm{~cm}$ & 0.34 & -0.22 & -0.27 & -0.45 & -0.59 & -0.56 \\
$40 \mathrm{~cm}$ & 0.34 & 0.21 & 0.03 & -0.28 & -0.24 & -0.54 \\
Mean & 0.18 & 0.08 & -0.07 & -0.43 & -0.26 & -0.70 \\
\hline
\end{tabular}

observed in deep soil near the dropper, while low $\mathrm{Zn}$ levels were found in surface soil in the vicinity of the dropper. Moreover, the $\mathrm{Zn}$ contents were usually lower in soil away from the dropper.

\section{Discussion}

Concentrations of $\mathrm{Cr}$ and $\mathrm{Cu}$ were much higher than the background level in both surface soil and deep soil under W1. These findings indicated that $\mathrm{Cr}$ and $\mathrm{Cu}$ obviously accumulated in soil from anthropogenic sources. $\mathrm{Zn}$ accumulated slightly in the surface soil. The concentrations of other metals in surface soil and deep soil were similar to the background values, indicating little accumulation. The significantly variable metal contents in surface soil among different distances from the dropper area suggested that the distributions of metals might be influenced by transportation of soil water. Under $\mathrm{W} 2, \mathrm{Cd}, \mathrm{Cr}, \mathrm{Cu}$, and $\mathrm{Zn}$ generally accumulated in both surface soil and deep soil. The metal concentrations in both surface soil and deep soil varied slightly among distances from the dropper.

Higher contents of $\mathrm{Cr}$ and $\mathrm{Cu}$ and lower levels of $\mathrm{Cd}$ were observed in surface soil and deep soil under W1 than W2. These findings indicated that the lower amount of irrigation water might cause higher accumulation of $\mathrm{Cr}$ and $\mathrm{Cu}$ in both surface soil and deep soil. Higher levels of irrigation water might induce $\mathrm{Cd}$ accumulation in soil. $\mathrm{Zn}$ usually accumulated in surface soil under W1, which suggests that Zn was obviously accumulated in deep soil under W2. However, Ni accumulation in surface soil and deep soil was hardly affected by the amount of irrigation water.

The $I_{\text {geo }}$ values of the metals revealed that $\mathrm{Cr}$ and $\mathrm{Cu}$ in both surface soil and deep soil under W1 was generally uncontaminated to moderately contaminated $\left(0<I_{\mathrm{geo}} \leq 1\right)$, while $\mathrm{Cd}, \mathrm{Pb}, \mathrm{Zn}$, and $\mathrm{Ni}$ fell into the category of uncontaminated. Under W2, the surface soil and deep soil were uncontaminated to moderately contaminated by $\mathrm{Cd}$ and $\mathrm{Cr}$. However, the soil was uncontaminated by $\mathrm{Cu}, \mathrm{Pb}, \mathrm{Zn}$, and $\mathrm{Ni}$.

The distribution patterns of the determined metals varied widely between W1 and W2. Cd mainly accumulated in surface soil and deep soil near the dropper, as well as in subsurface soil away from the dropper under $\mathrm{W} 1$, while $\mathrm{Cd}$ was obviously accumulated in surface soil and subsurface soil under W2. These findings suggested that lower irrigation water amount might cause upward $\mathrm{Cd}$ migration to the surface soil away from the dropper. With increasing amounts of irrigation water, $\mathrm{Cd}$ moved to the surface soil and deep soil away from the dropper. Cr usually migrated from surface soil to subsurface soil in the vicinity of the dropper under W1 and W2. Moreover, $\mathrm{Cr}$ primarily accumulated in surface soil and deep soil away from the dropper. The results also revealed that migration of $\mathrm{Cr}$ was more obvious under higher irrigation 

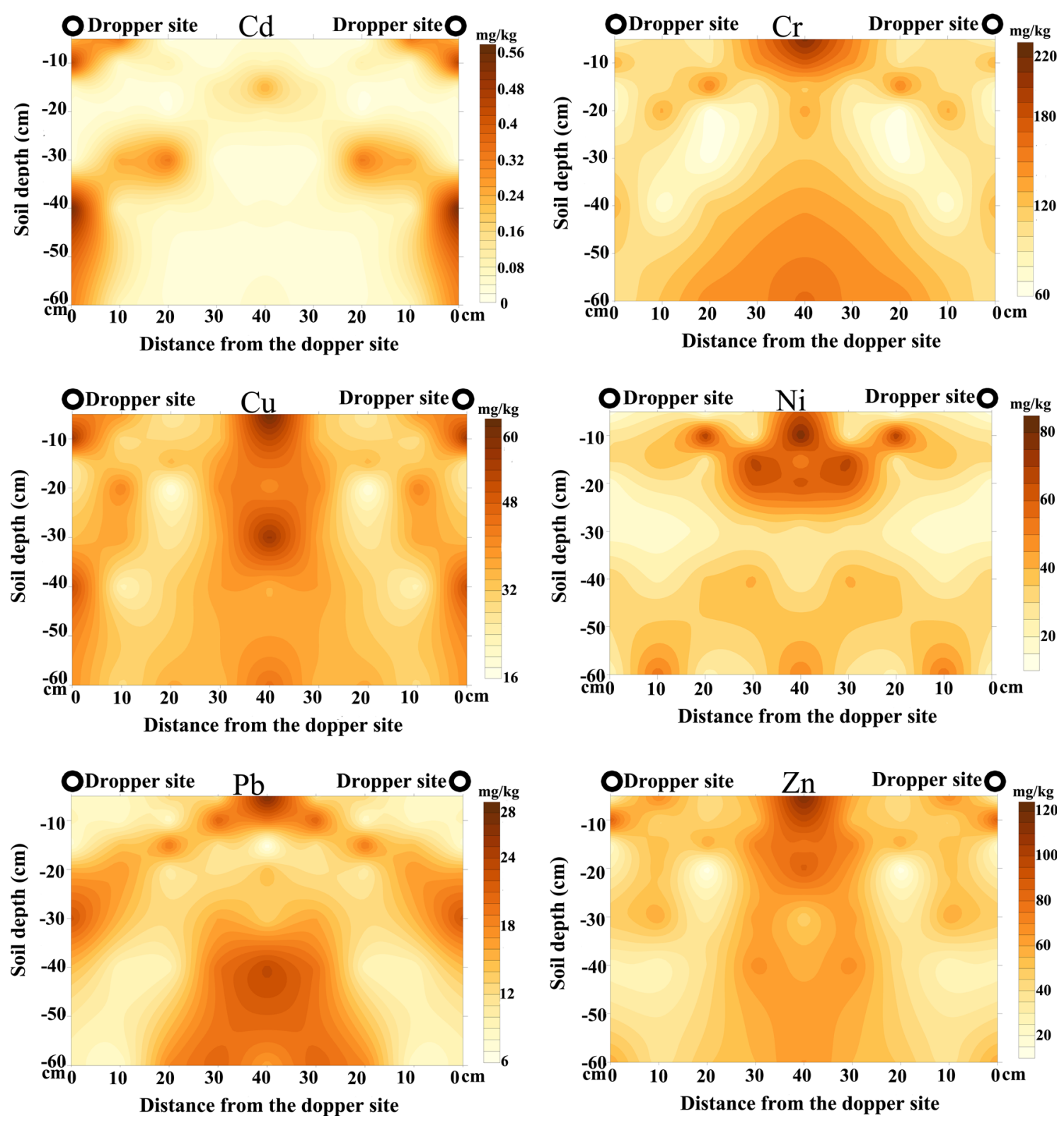

Fig. 2 Distributions of heavy metal concentrations in soil under W1

water amounts. Under $\mathrm{W} 1, \mathrm{Cu}$ primarily moved from subsurface soil to surface soil near the dropper. Away from the dropper, there was significant $\mathrm{Cu}$ accumulation in soil. However, leaching of $\mathrm{Cu}$ was observed in a small area near the dropper under W2. The Ni migration characteristics were similar between W1 and W2. Ni usually accumulated in surface soil and deep soil away from the dropper. The higher Ni concentration in deep soil under W2 indicated that higher amounts of irrigation water promoted leaching of Ni. Under $\mathrm{W} 1$ and $\mathrm{W} 2, \mathrm{~Pb}$ generally leached in the vicinity of the dropper, while the migration of $\mathrm{Pb}$ in the other parts varied widely between $\mathrm{W} 1$ and $\mathrm{W} 2$. The downward transportation of $\mathrm{Pb}$ was gradually decreased with increasing distance from the dropper, which induced accumulation of $\mathrm{Pb}$ in subsurface soil near the dropper and surface soil away from the dropper. $\mathrm{Zn}$ tended to leach in the vicinity of the dropper area under both $\mathrm{W} 1$ and $\mathrm{W} 2$. The leaching ability of $\mathrm{Zn}$ was more obvious under $\mathrm{W} 2$ than under $\mathrm{W} 1$, indicating that higher irrigation water amount increased the leaching ability of $\mathrm{Zn}$ in soil under the dropper area. Moreover, lower irrigation water amount promoted $\mathrm{Zn}$ horizontal migration away from the dropper area. In contrast, higher irrigation water amount usually induced downward migration of $\mathrm{Zn}$ near the dropper area.

In summary, the migration characteristics of the determined metals were usually affected by drip irrigation. $\mathrm{Cr}, \mathrm{Ni}, \mathrm{Pb}$, and $\mathrm{Zn}$ were leached to subsurface soil in a small area under the dropper. $\mathrm{Cd}$ and $\mathrm{Cu}$ moved to the surface soil under lower irrigation water amounts, while they were leached under higher irrigation water amounts. In addition, metals usually accumulated in surface soil and deep soil away from the 

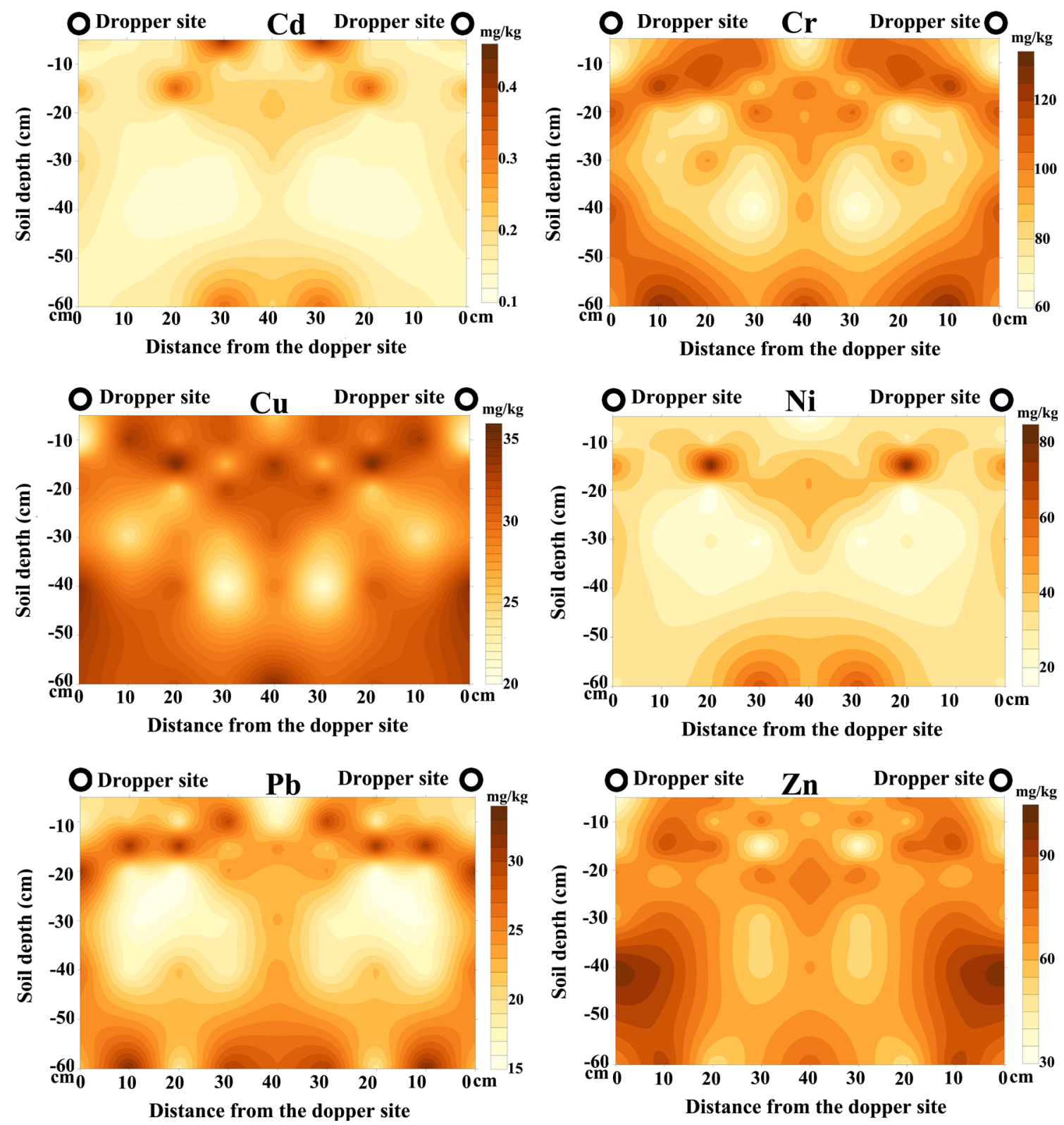

Fig. 3 Distributions of heavy metal concentrations in soil under W2

dropper under lower irrigation water amounts. However, $\mathrm{Cr}$, $\mathrm{Cu}, \mathrm{Pb}$, and $\mathrm{Zn}$ usually accumulated in subsurface soil and deep soil near the dropper under higher irrigation water amounts. Away from the dropper, $\mathrm{Cd}, \mathrm{Cr}, \mathrm{Pb}, \mathrm{Ni}$, and $\mathrm{Zn}$ obviously migrated to surface soil and deep soil.

The migration of metals might be significantly associated with water spreading. Ajwa and Trout (2004) reported that pesticides applied through a drip irrigation system were usually distributed through the soil by the infiltrating water, with little movement beyond the wetted area. In the present study, lower irrigation water amount significantly affected horizontal migration of heavy metals, while higher irrigation water amount usually influenced vertical movement of heavy metals. This might be attributed to water spreading. The spread of water from drip sources is generally affected by various soil physical properties, irrigation water amount, evaporation, and other factors (Cote et al. 2003; Thorburn et al. 2003; Gärdenäs et al. 2005). The movement of soil moisture in the horizontal direction expanded with increasing irrigation water amount. Additionally, the water infiltration depth was positively associated with irrigation water amount (Chen et al. 2010). However, these factors were not investigated in the present study. Moreover, the relationships between bioavailability of heavy metal, soil chemical and physical properties, and drip irrigation were not discussed. Therefore, future studies investigating the factors impacting the migration and bioavailability of heavy metals as well as changes in soil chemical and physical properties under drip irrigation are warranted. 


\section{Conclusions}

The results of the present study revealed that the mean concentrations of $\mathrm{Cd}, \mathrm{Cr}, \mathrm{Cu}, \mathrm{Ni}, \mathrm{Pb}$, and $\mathrm{Zn}$ in surface soils varied significantly between $\mathrm{W} 1$ and $\mathrm{W} 2$, as well as among different distances from the dropper. With the exception of $\mathrm{Zn}$, the mean concentrations of the other metals varied slightly between surface soil and deep soil under both W1 and W2. The cultivated soil was contaminated with $\mathrm{Cr}, \mathrm{Cd}$, and $\mathrm{Cu}$. These findings indicated that drip irrigation affected the distribution and migration of heavy metals in soil. The migration characteristics of heavy metals were significantly influenced by irrigation water amount. However, the factors impacting the migration of heavy metals, their bioavailability, and the changes in soil chemical and physical properties under drip irrigation should be further investigated.

Acknowledgments The work described in this article was financially supported by the National Public Welfare Sectors (Agriculture) special research (No. 201203012-6) and the State Key Program of National Natural Science of China (No. 41230749).

\section{References}

Ajwa HA, Trout T (2004) Drip application of alternative fumigants to methyl bromide for strawberry production. Hortic Sci 39:17071715

Al-Hwaiti M, Al-Khashman O (2015) Health risk assessment of heavy metals contamination in tomato and green pepper plants grown in soils amended with phosphogypsum waste materials. Environ Geochem Health 37:287-304

Badr AE, Abuarab ME (2013) Soil moisture distribution patterns under surface and subsurface drip irrigation systems in sandy soil using neutron scattering technique. Irrig Sci 31:317-332

Baldantoni D, Leone A, Iovieno P, Morra L, Zaccardelli M, Alfani A (2010) Total and available soil trace element concentrations in two Mediterranean agricultural systems treated with municipal waste compost or conventional mineral fertilizers. Chemosphere 80: 1006-1013

Burges A, Epelde L, Garbisu C (2015) Impact of repeated single-metal and multi metal pollution events on soil quality. Chemosphere 120: $8-15$

Chen B, Cao J, Wang L, Mao J (2010) Research on distribution and movement rules of soil water under different drip irrigation conditions. Water Sav Irrig 7:6-10

Cheraghi M, Lorestani B, Merrikhpour H (2012) Investigation of the effects of phosphate fertilizer application on the heavy metal content in agricultural soils with different cultivation patterns. Biol Trace Elem Res 145:87-92

CNEMC (China National Environmental Monitoring Centre) (1990) The background values of Chinese soils. Environmental Science Press of China, Beijing

Cote CM, Bristow KL, Charlesworth PB, Cook FJ, Thorburn PJ (2003) Analysis of soil wetting and solute transport in subsurface trickle irrigation. Irrig Sci 22:143-156

Fonseca AF, Melfi AJ, Montes CR (2005) Maize growth and changes in soil fertility after irrigation with treated sewage effluent. II. Soil acidity, exchangeable cations, and sulfur, boron, and heavy metals availability. Commun Soil Sci Plant 36:1983-2003
Gärdenäs AI, Hopmans JW, Hanson BR, Šimůnek J (2005) Two dimensional modeling of nitrate leaching for various fertigation scenarios under micro-irrigation. Agric Water Manag 74:219-242

Guan H, Li J, Li Y (2013) Effects of drip system uniformity and irrigation amount on water and salt distributions in soil under arid conditions. J Integr Agric 12(5):924-939

$\mathrm{Hu} \mathrm{H}$, Tian F, Hu H (2011) Soil particle size distribution and its relationship with soil water and salt under mulched drip irrigation in Xinjiang of China. Sci China Technol Sci 54:1568-1574

Ji Y, Feng Y, Wu J, Zhu T, Bai Z, Duan C (2008) Using geo-accumulation index to study source profiles of soil dust in China. J Environ Sci 20: $571-578$

Kandelous MM, Šimůnek J, van Genuchten MT, Malek K (2011) Soil water content distributions between two emitters of a subsurface drip irrigation system. Soil Sci Soc Am J 75:488-497

Koedrith P, Kim H, Weon JI, Seo YR (2013) Toxicogenomic approaches for understanding molecular mechanisms of heavy metal mutagenicity and carcinogenicity. Int J Hyg Environ Health 216:587-598

Liu M, Yang J, Li X, Yu M, Wang J (2012) Effects of irrigation water quality and drip tape arrangement on soil salinity, soil moisture distribution, and cotton yield (Gossypium hirsutum L.) under mulched drip irrigation in Xinjiang, China. J Integr Agric 11(3):502-511

Liu M, Yang J, Li X, Liu G, Yu M, Wang J (2013) Distribution and dynamics of soil water and salt under different drip irrigation regimes in northwest China. Irrig Sci 31:675-688

Luo X, Xue Y, Wang Y, Cang L, Xu B, Ding J (2015) Source identification and apportionment of heavy metals in urban soil profiles. Chemosphere 127:152-157

Maimaitiniyazi N, Zheng X, Batur B, Li H, Ruxian M, He F (2011) An analysis of water and salt transport under drip irrigation conditions. J Shandong Agr Univ 42(4):551-554

Muller G (1969) Index of geo-accumulation in sediments of the Rhine River. GeoJournal 2:108-118

Negreanu Y, Pasternak Z, Jurkevitch E, Cytryn E (2012) Impact of treated wastewater irrigation on antibiotic resistance in agricultural soils. Environ Sci Technol 46:4800-4808

Qiao Z, Peng S, Xu J, Gao X, Song J (2011) Chemical forms and migration of soil heavy metals in paddy and effects or irrigation. J Anhui Agric Sci 39(16):9698-9700

Rai S, Gupta S, Mittal PC (2015) Dietary intakes and health risk of toxic and essential heavy metals through the food chain in agriculture, industrial, and coal mining areas of Northern India. Hum Ecol Risk Assess 21:913-933

Rajmohan N, Prathapar SA, Jayaprakash M, Nagarajan R (2014) Vertical distribution of heavy metals in soil profile in a seasonally waterlogging agriculture field in Eastern Ganges Basin. Environ Monit Assess 186:5411-5427

Savic R, Ondrasek G, Josimov-Dundjerski J (2015) Heavy metals in agricultural landscapes as hazards to human and ecosystem health: a case study on zinc and cadmium in drainage channel sediments. J Sci Food Agric 95:466-470

Selim T, Bouksila F, Berndtsson R, Persson M (2013) Soil water and salinity distribution under different treatments of drip irrigation. Soil Sci Soc Am J 77:1144-1156

Soltani N, Keshavarzi B, Moore F, Tavakol T, Lahijanzadeh AR, Jaafarzadeh N, Kermani M (2015) Ecological and human health hazards of heavy metals and polycyclic aromatic hydrocarbons (PAHs) in road dust of Isfahan metropolis, Iran. Sci Total Environ 505:712-723

Soodan RK, Pakade YB, Nagpal A, Katnoria JK (2014) Analytical techniques for estimation of heavy metals in soil ecosystem: a tabulated review. Talanta 125:405-410

Surdyk N, Cary L, Blagojevic S, Jovanovic Z, Stikic R, VucelicRadovic B, Zarkovic B, Sandei L, Pettenati M, Kloppmann W (2010) Impact of irrigation with treated low quality water on the heavy metal contents of a soil-crop system in Serbia. Agric Water Manag 98:451-457 
Tan J, Kang Y, Jiao Y, Liu W, Dong F (2009) Effects of cropping years on soil salinity and $\mathrm{pH}$ value in fields under drip irrigation condition. Trans CSAE 25(9):43-50

Thorburn PJ, Cook FJ, Bristow KL (2003) Soil-dependent wetting from trickle emitters: Implications for system design and management. Irrig Sci 22:121-127

Wei B, Yang L (2010) A review of heavy metal contaminations in urban soils, urban road dusts and agricultural soils from China. Microchem J 94:99-107

Wei B, Jiang F, Li X, Mu S (2010) Heavy metal induced ecological risk in the city of Urumqi, NW China. Environ Monit Assess 160:33-45

Yang L, Peterson PJ, Williams WP, Wang WY, Hou SF, Tan JA (2002) The relationship between exposure to arsenic concentrations in drinking water and the development of skin lesions in farmers from Inner Mongolia, China. Environ Geochem Health 24:293-303

Zhang XW, Yang LS, Li YH, Li HR, Wang WY, Ye BX (2012) Impacts of lead/zinc mining and smelting on the environment and human health in China. Environ Monit Assess 184:2261-2273

Zheng X, Batur B, Li H, Jia W, Zhao H (2011) Effect of irrigation methods on movement of soil water and salt in arid area. J Northeast Agric Univ 42(5):95-98

Zhou L, Yang B, Xue N, Li F, Seip HM, Cong X, Yan Y, Liu B, Han B, Li $H$ (2014) Ecological risks and potential sources of heavy metals in agricultural soils from Huanghuai Plain, China. Environ Sci Pollut Res 21:1360-1369

Żukowska J, Biziuk M (2008) Methodological evaluation of method for dietary heavy metal intake. J Food Sci 73:R21-R29 